\title{
PERAN GENDER DAN KESADARAN METAKOGNITIF SISWA SMA DI KABUPATEN KUNINGAN TERHADAP HASIL BELAJAR BIOLOGI
}

\author{
Wawan Hermawan $^{\text {1) }}$, Zaenal Abidin ${ }^{2)}$, Edi Junaedi ${ }^{3)}$ \\ ${ }^{1}$ Mahasiswa Program Studi Pendidikan Biologi FKIP, Universitas Kuningan \\ Email :wh34227@gmail.com \\ ${ }^{2}$ Dosen Program Studi Pendidikan Biologi FKIP, Universitas Kuningan \\ Email : zaenal.abidin@uniku.ac.id \\ Email : edi.junaedi@uniku.ac.id
}

APA Citation: Hermawan, W, Abidin, Z., \& Junaedi, E. (2018). Peran Gender Dan Kesadaran Metakognitif Siswa SMA Di Kabupaten Kuningan Terhadap Hasil Belajar Biologi. Quagga: Jurnal Pendidikan dan Biologi, 10(2), 11-18. doi: 10.25134/quagga.v10i2.904.

Received: 26-03-2018

Accepted: 28-07-2018

Published: 30-07-2018

\begin{abstract}
Abstrak: Penelitian ini bertujuan untuk mengetahui peran gender dan kesadaran metakognitif siswa SMA terhadap hasil belajar kognitif biologi. Penelitian menggunakan metode survey dengan populasi adalah siswa kelas XI IPA SMA Negeri di Kabupaten kuningan yang melaksanakan kurikulum 2013. Sampel penelitian sebanyak 253 siswa dengan teknik cluster random sampling. Instrumen penelitian adalah angket MAI (Metacognitive Awareness Inventory) untuk mengetahui tingkat kesadaran metakognitif. Analisis data untuk mengetahui pengaruh gender dan kesadaran metakognitif terhadap hasil belajar menggunakan regresi linier berganda. Distribusi frekuensi setiap variabel di analisis menggunakan deskriptif frequencies. Analisisperbedaan rata- rata hasil belajar antara siswa laki-laki dan siswa perempuan mengunakan T-test. Hasil penelitian menunjukkan bahwa ; 1) tidak ada pengaruh gender terhadap hasil belajar biologi siswa 2) terdapat pengaruh kesadaran metakognitif terhadap-hasil belajar biologi dan 3) terdapat pengaruh gender dan kesadaran metakognitif secara bersama-sama terhadap hasil belajar biologi.Kata kunci: gender, kesadaran metakognitif, dan hasil belajar biologi
\end{abstract}

\begin{abstract}
This study aims to determine the gender role and metacognitive awareness of high school students on cognitive biology learning outcomes. The study used a survey method with a population of students of class XI IPA of State High Schools in Kuningan District who carried out the 2013 curriculum. The study sample was 253 students with cluster random sampling technique. The research instrument was the MAI questionnaire (Metacognitive Awareness Inventory) to determine the level of metacognitive awareness. Data analysis to determine the effect of gender and metacognitive awareness on learning outcomes using multiple linear regression. The frequency distribution of each variable in the analysis uses descriptive frequencies. Analysis ofdifferences in average learning outcomes between male and female students using a T-test. The results of the study show that; 1) there is no gender influence on students' biology learning outcomes 2) there is an influence of metacognitive awareness on biology learning outcomes and 3) there are gender influences and metacognitive awareness together on biology learning outcomes.
\end{abstract}

Keywords: gender, metacognitive awareness, and biology learning outcomes

\section{PENDAHULUAN}

Mutu pendidikan di Indonesia saat ini tercermin dari hasil survei Programme for International Student Assessment (PISA) pada tahun 2015 tentang prestasi anak Indonesia dalam bidang sains yang masih di bawah ratarata skor internasional, yakni 403 (skor rata-rata internasional adalah 501). Pencapaian anak Indonesia dalam bidang sains berada pada urutan ke-62 dari 70 negara yang diteliti (OECD, 2016: 5).
Berdasarkan data statistik Sekolah Menengah Atas tahun 2015/2016 Kemendikbud. Jumlah siswa SMA menurut jenis kelamin, untuk siswa laki-laki sebanyak 1.918 .845 sementara siswa perempuan berjumlah 2.393.562. data tersebut menunjukan bahwa pada jenjang SMA jumlah pelajar perempuan mendominasi dibandingkan pelajar laki-laki.

Dominasi perempuan di sekolah bukan hanya dari segi kuantitas, melainkan hasil belajar siswa perempuan lebih unggul dan mendominasi dari pada siswa laki-laki. The Economist 
Quagga: Jurnal Pendidikan dan Biologi

Volume 10, Nomor 2, Juli 2018

mengamati bahwa anak perempuan diberbagai negara tampak mengungguli anak laki-laki sebelum mulai sekolah dan sampai akhir sekolah lanjutan (Dryden dan Vos, 1999).Menurut Survei Programme for International Student Assessment (PISA) pada tahun 2015 tentang harapan karir siswa indonesia terkait sains, untuk laki-laki 8.6 dan perempuan 22.1, dimana perempuan lebih mempunya expectasi yang tinggi terhadap sains dibandingkan laki-laki. Dengan kemungkinan peningkatan siswa lakilaki melanjutkan karir dalam sains hanya sebesar 0,4 (OECD, $2016: 7$ ).

Metakognitif merupakan salah satu aspek pengetahuan yang termaktub dalam standar kompetensi lulusan untuk Sekolah Menengah Atas (SMA) dalam kurikulum 2013. Teori metakognisi menyatakan bahwa kemampuan metakognisi adalah kemampuan mengintegrasikan pengetahuan kognitif dan regulasi kognitif (Scraw \& Moshman, 1995). Menurut Flavell \{(1979) dalam Kristiani (2015)\} Metakognisi mengacu pada kesadaran dan pemantauan pikiran seseorang dan kinerja tugas, atau lebih sederhana, berpikir tentang pemikiran seseorang.

Menurut Moore, \{(2004) dalam Kristiani, (2015)\} metakognisi merupakan kesadaran berpikir seseorang tentang proses berpikirnya sendiri baik tentang apa yang diketahui maupun apa yang akan dilakukan. Berdasarakan hal tersebut metakognisi melibatkan kesadaran seseorang untuk berpikir dan bertindak. Dari pernyataan di atas dapat disimpulkan bahwa kesadaran metakognisi ada kaitannya dengan kemampuan kognitif seseorang. Sejalan dengan hal itu maka kesadaran metakognitif berhubungan dengan hasil belajar kognitif siswa.

Menurut Nuryana dan Sugiarto (2012) metakognitif adalah kesadaran tentang apa yang diketahui dan apa yang tidak diketahui. Apabila kesadaran ini terwujud maka seseorang dapat memulai pemikirannya dengan merancang, memantau dan menilai apa yang dipelajari. Menurut Nuryana dan Sugiarto (2012) Hasil belajar pada hakekatnya adalah perubahan tingkah laku sebagai hasil dari proses belajar mengajar. Menurut Nuryana dan Sugiarto (2012) Proses belajar dikatakan berlangsung efektif apabila hasil belajar yang dicapai siswa dapat mencapai indikator yang telah ditetapkan.

Menurut penelitian yang dilakukan Nuryana dan Sugiarto (2012), mengatakan bahwa terdapat hubungan yang signifikan antara
p-ISSN 1907-3089, e-ISSN2651-5869

https://journal.uniku.ac.id/index.php/quagga

kesadaran metakognisi dengan hasil belajar siswa. Semakin tinggi kesadaran metakognisi siswa maka semakin tinggi pula hasil belajar siswa. Hasil penelitian Coutinho (2007) juga melaporkan hubungan yang positif antara kesadaran metakognisi dengan kesuksesan akademik. Oleh karena itu, penting untuk memperhatikan dan pengembangan kesadaran metakognitif siswa di sekolah, selain memperhatikan aspek perbedaan gender.

Pemberdayaan kesadaran metakognitif siswa dalam pembelajaran akan berimplikasi terhadap perolehan hasil belajar lainnya, seperti hasil belajar kognitif (Livingstone, 1997 dalam Arifin dan Saenab, 2014). Menurut Ormrod (2009) semakin banyak pembelajar tahu tentang proses berfikir dan belajar, yaitu semakin besar kesadaran metakognitif mereka, semakin baik proses belajar dan prestasi yang mungkin mereka capai (Hofer \& Pintrich, 2002; Perkins, 1995; Schneider \& Lockl, 2002).

Berdasarkan obervasi lapangan terkait kesenjangan gender juga ditemukan pada saat PPL (Pelaksanan Pengalaman Lapangan) yang dilaksanakan di SMA Negeri 2 Kuningan. Menunjukkan bahwa hasil belajar siswa perempuan lebih unggul dari pada siswa laki laki. Setidaknya tercermin dari prestasi belajar siswa pada semester 1. Dari ke 40 siswa di kelas X.4 dari jumlah laki-laki sebanyak 14 siswa dan perempuan berjumlah 26 siswa. Yang masuk 3 terbaik di kelas semuanya siswa perempuan.Berdasarkan identifikasi masalah tersebut, kajian ini bertujuan untuk mengetahui pengaruh gender dan kesadaran metakognitif Siswa SMA terhadap biologi.

\section{METODOLOGI PENELITIAN \\ Tempat dan Waktu Penelitian}

Penelitian ini dilakukan di tiga Sekolah Menengah Atas Negeri di Kabupaten Kuningan yang sedang melaksanakan Kurikulum 2013, yang ditentukan secara purposive sampling area. Pengambilan data dilaksanakan pada Bulan Mei 2017 semester genap Tahun Ajaran 2016-2017.

\section{Metode Penelitian}

Metode yang digunakan dalam penelitian ini adalah metode Survey. Instrumen yang digunakan adalah Kuesioner MAI (Metacognitive Awareness Inventory) yang dikembangkan dari Schraw \& Dennison (1994). 
Quagga: Jurnal Pendidikan dan Biologi

Volume 10, Nomor 2, Juli 2018

\section{Populasi dan Sampel}

Subjek penelitian adalah 253 siswa kelas XI IPA dari populasi sebanyak 680 siswa. Sampel dipilih secara cluster random sampling.

\section{Analisis data}

Data peran gender dan kesadaran metakognitif siswa terhadap hasil belajar biologi dianalisis menggunakan regresi ganda melalui SPSS versi 21. Sebelumnya data tersebut diuji normalitasnya, multikolinearitasnya dan heteroskedastisitasnya.

\section{HASIL DAN PEMBAHASAN}

\section{Pengujian Hipotesis Secara Parsial (Uji t)}

Pengujian hipotesis secara parsial dimaksudkan untuk menguji pengaruh masingmasing variabel bebas, yaitu (X1) gender dan (X2) kesadaran metakognitif siswa terhadap hasil belajar Biologi (Y). Adapun ringkasan hasil analisis $\mathrm{X} 1$ terhadap $\mathrm{Y}$ dapat dilihat pada Tabel 1.

Tabel 1. Uji Parsial Gender

\begin{tabular}{cccccc}
\hline Variabel & $\mathbf{N}$ & $\begin{array}{c}\text { Harga } \\
\text { t- } \\
\text { Hitung }\end{array}$ & $\begin{array}{c}\text { Harga } \\
\text { t-Tabel }\end{array}$ & Sig. & Keterangan \\
\hline $\begin{array}{c}\text { Gender } \\
(\mathrm{X} 1)\end{array}$ & 253 & 1,407 & 1,969 & 0,161 & H0 diterima \\
\hline
\end{tabular}

Sumber: Data penelitian setelah diolah dengan SPSS 21

Berdasarkan Tabel 1. dapat diketahui $t$ hitung, yaitu 1,407 dan t tabel, yaitu 1,969. Artinya t-hitung < t-tabel, jadi hipotesis nol diterima. Kesimpulannya adalah gender tidak berpengaruh terhadap hasil belajar Biologi siswa. Nilai koefisiensi dan t-hitung adalah positif sehingga gender berpengaruh positif terhadap hasil belajar Biologi siswa. Adapun ringkasan hasil analisis X2 terhadap $\mathrm{Y}$ dapat dilihat pada Tabel 2.

Tabel 2. Uji Parsial Kesadaran Metakognitif

\begin{tabular}{cccccc}
\hline Variabel & $\mathbf{N}$ & $\begin{array}{c}\text { Harga } \\
\text { t- } \\
\text { Hitung }\end{array}$ & $\begin{array}{c}\text { Harga } \\
\text { t-Tabel }\end{array}$ & Sig. & Keterangan \\
\hline $\begin{array}{c}\text { Kesadaran } \\
\begin{array}{c}\text { Metakognitif } \\
\text { (X2) }\end{array}\end{array}$ & 253 & 19,204 & 1,969 & 0,000 & Ha diterima \\
\hline
\end{tabular}

Sumber : Data penelitian setelah diolah dengan SPSS 21

Berdasarkan Tabel 2. dapat diketahui thitung, yaitu 19,204) dan t-tabel, 1,969. Artinya
p-ISSN 1907-3089, e-ISSN2651-5869

https://journal.uniku.ac.id/index.php/quagga

t-hitung > t-tabel, hipotesis nol ditolak. Kesimpulannya adalah Kesadaran metakognitif siswa berpengaruh terhadap hasil belajar Biologi. Nilai koefisiensi dan t-hitung adalah positif sehingga kesadaran metakognitif siswa berpengaruh positif terhadap hasil belajar Biologi siswa.

\section{Uji Hipotesis Simultan (Uji F)}

Pengujian hipotesis secara simultan (bersama-sama) digunakan untuk mengetahui sejauh mana variabel kesadaran metakognitif dan gender berpengaruh terhadap hasil belajar biologi secara simultan (bersama-sama). Adapun ringkasan hasil analisis $\mathrm{X} 1$ dan $\mathrm{X} 2$ terhadap $\mathrm{Y}$ dapat dilihat pada Tabel 3.

Tabel 3. Hasil Uji Simultan

\begin{tabular}{cccccc} 
Sumber & $\mathbf{N}$ & $\begin{array}{c}\text { Harga F-Harga F- } \\
\text { Hitung }\end{array}$ & Tabel & Sig. & Keterangan \\
\hline Regresi & 253 & 188,04 & 3,032 & 0,000 & Ha diterima \\
\hline Sumber : Data penelitian setelah diolah dengan \\
SPSS 21
\end{tabular}

Berdasarkan Tabel 3, hasil uji simultan untuk regresi diperoleh diperoleh F-hitung 188,040 dan F- tabel sebesar 3,0319. Artinya F hitung $>\mathrm{F}$ tabel pada level signifikan $(0,05)$ jadi hipotesis nol ditolak. Dapat disimpulkan bahwa secara simultan (bersama-sama) kesadaran metakognitif dan gender berpengaruh terhadap hasil belajar biologi.

\section{Analisis Koefisien Determinasi}

Tabel 4. Menunjukkan nilai adjusted $\mathrm{R}$ square dengan bantuan SPSS 21.

Tabel 4. Koefisien Determinasi Simultan Model

\begin{tabular}{ccccc}
\multicolumn{5}{c}{ Summary } \\
\hline Model & $\mathrm{R}$ & $\begin{array}{c}\mathrm{R} \\
\text { Square }\end{array}$ & $\begin{array}{c}\text { Adjusted } \\
\mathrm{R} \text { Square }\end{array}$ & $\begin{array}{c}\text { Std. Error } \\
\text { Of The } \\
\text { Estimate }\end{array}$ \\
\hline 1 &, $775^{\mathrm{a}}$ &, 601 &, 597 & 3,418 \\
\hline \multicolumn{5}{c}{ Sumber : Data penelitian setelah diolah dengan } \\
SPSS 21
\end{tabular}

Berdasarkan hasil output SPSS 21 yang tertera pada Tabel 4. dapat disimpulkan bahwa ilai adjusted $\mathrm{R}$ square (R2) sebesar 0,597, yang berarti $59,7 \%$. Nilai tersebut menunjukkan bahwa $50,7 \%$ hasil belajar biologi dapat dipengaruhi oleh kesadaran metakognitif dan gender. Selebihnya, 40,3\% variabel hasil belajar dipengaruhi oleh faktor lain di luar model regresi ini. 
Nilai Standar Error of the Estimate (SEE) yang diperoleh adalah 3,418. Nilai tersebut lebih kecil dari pada standar deviasi variabel dependen, yaitu 5,387. Semakin kecil nilai SEE dari standar deviasi variabel dependen (hasil belajar biologi siswa), semakin tepat model regresi dalam memprediksi variabel dependen.

\section{Hubungan Gender Siswa dengan Hasil Belajar Biologi}

Hubungan antara gender siswa dan hasil Belajar Biologi dianalisis dengan korelasi product moment menggunakan SPSS 21.

Tabel 5. Korelasi Antara Gender Siswa dan Hasil Belajar Biologi

\begin{tabular}{cccc}
\hline & & Gender & $\begin{array}{c}\text { Hasil } \\
\text { belajar }\end{array}$ \\
\cline { 3 - 4 } & & &, 108 \\
\hline Gender & Pearson Correlation & 1 &, 087 \\
& Sig. (2-tailed) & & 253 \\
& N & 253 & 1 \\
Hasil & Pearson Correlation &, 108 & 1 \\
Belajar & Sig. (2-tailed) &, 087 & \\
& & & \\
& N & 253 & 253
\end{tabular}

Sumber : Data penelitian setelah diolah dengan SPSS 21

Berdasarkan output pada Tabel 5. diketahui bahwa korelasi antara variabel gender siswa dan hasil belajar biologi dengan nilai koefisiensi 0,108 . Nilai ini menunjukkan hubungan rendah karena berada pada rentang 0,00-0,199. Artinya, hubungan antara gender siswa dan hasil belajar sangat rendah.

\section{Hubungan antara Kesadaran Metakognitif Siswa dan Hasil Belajar Biologi}

Hubungan antara kesadaran metakognitif siswa dan hasil belajar biologi dianalisis menggunakan korelasi product moment menggunakan SPSS 21.

Tabel 6. Korelasi Antara Kesadaran Metakognitif Siswa dengan Hasil Belajar Biologi

\begin{tabular}{llcc}
\hline & Pearson & $\begin{array}{c}\text { Hasil } \\
\text { belajar }\end{array}$ & $\begin{array}{c}\text { Kesadaran } \\
\text { Metakognitif }\end{array}$ \\
\cline { 3 - 4 } & Correlation & 1 &, $773^{* *}$ \\
\hline Hasil belajar & $\begin{array}{l}\text { Sig. (2-tailed) } \\
\text { N }\end{array}$ & 253 &, 000 \\
& $\begin{array}{l}\text { Pearson } \\
\text { Correlation }\end{array}$ &, $773^{* *}$ & 1 \\
Kesadaran & Sig. (2-tailed) &, 000 & \\
metakognitif & $\mathrm{N}$ & 253 & 253 \\
\hline
\end{tabular}

Berdasarkan output pada Tabel 6. Dapat diketahui bahwa korelasi antara variabel kesadaran metakognitif siswa hasil belajar
Biologi dengan nilai koefisiensi 0,773. Hubungan ini Kuat karena berada pada rentang 0,60-0,799, dapat diartikan bahwa hubungan kesadaran metakognitif siswa dan hasil belajar kuat.

\section{Pembahasan}

\section{Pengaruh Gender terhadap Hasil Belajar Biologi Siswa}

Berdasarkan hasil analisis gender tidak memberikan pengaruh signifikan terhadap hasil belajar biologi siswa. Kondisi tersebut sejalan dengan hasil penelitian yang dilakukan oleh Brasilita (2016) yang mengungkapkan bahwa perbedaan jenis kelamin tidak berpengaruh terhadap hasil belajar kognitif siswa. Hasil tersebut berbeda dengan hasil kajian Siregar (2014) yang menyarakan bahwa jenis kelamin adalah salah satu faktor yang berasal dari dalam diri siswa yang mempengaruhi hasil belajar.

Secara biologis, perbedaan beberapa struktur otak memungkinkan siswa laki-laki dan siswa perempuan berbeda dalam kemampuan memproses, menanggapi informasi, atau menyimpan informasi jangka panjang. (Pambudiono 2012). Lebih lanjut Sasser (2010) menjelaskan bahwa perempuan umumnya memiliki hippocampus lebih besar dari pada lakilaki, sehingga berpotensi meningkatkan memori penyimpanan jangka panjang yang lebih baik. Selain itu, bagian otak lain yang memiliki struktur berbeda antara laki-laki dan perempuan adalah bagian cerebral cortex yang mengontrol berpikir, pengambilan keputusan, dan fungsi intelektual. Lebih lanjut Sasser (2010) mengungkapkan bahwa otak perempuan menerima sekitar 20\% lebih banyak aliran darah dan memiliki koneksi saraf yang lebih banyak.

Akan tetapiberbeda dengan hasil kajian di atas Gallangher dalam Sugihartono (2007) menyatakan bahwa tidak ada bukti yang menghubungkan antara prestasi akademik dan perbedaan biologis laki-laki dan perempuan. Laki-laki dan perempuan memiliki perbedaan dalam perkembangan fisik, emosional, dan intelektual, tetapi tidak mempengaruhi prestasi akademik.

\section{Pengaruh Kesadaran Metakognitif terhadap Hasil Belajar Biologi Siswa}

Hasil penelitian menunjukkan bahwa kesadaran metakognitif siswa memberikan pengaruh positif dan signifikan terhadap Hasil Belajar Biologi. 
Hal tersebut selaras dengan penelitian yang dilakukan oleh Nuryana dan Sugiarto (2012) mengatakan bahwa terdapat hubungan yang signifikan antara kesadaran metakognisi dengan hasil belajar siswa. Semakin tinggi kesadaran metakognisi siswa maka semakin tinggi pula hasil belajar siswa. Hasil penelitian Coutinho (2007) juga menunjukkan hubungan yang positif antara kesadaran metakognisi dengan kesuksesan akademik. Hal tersebut selaras dengan penelitian yang dilakukan oleh Rahman at. all. (2006) yang menyimpulkan bahawa kesedaran metakognisi mempunyai hubungan langsung positif dan signifikan pada pencapaian akademik pelajar.

Menurut Nurmalasari, et. Al (2015) menyatakan bahwa kemampuan metakognisi pada dasarnya sudah dimiliki setiap individu. Pada saat-saat tertentu seseorang akan merefleksikan kemampuan dirinya dalam hal belajar dan memikirkan serta melakukan strategi-strategi untuk menyelesaikan tugas atau memecahkan masalah yang dihadapi dalam proses belajarnya. Akan tetapi, seseorang tidak menyadari bahwa yang dilakukan itu merupakan kegiatan metakognisi.

Siregar (2014) dalam Revisied Taksonomy, menjelaskan metakognitif sebagai salah satu kategori pada dimensi pengetahuan yang termasuk dalam faktor hasil belajar. Adapun beberapa aspek metakognisi yang mendukung siswa dalam mempelajari materi-materi pembelajaran menurut Schraw \& Dennison (1994) adalah pengetahuan kognisi (pengetahuan deklaratif, pengetahuan prosedural, pengetahuan kondisional) dan regulasi kognisi (perencanaan, strategi manajemen informasi, monitoring, strategi penelusuran, evaluasi). Kesadaran Metakognitif berkaitan erat dengan hasil belajar karena hasil belajar merupakan suatu hasil dari proses kognitif, sehingga ketika kesadaran metakognitif siswa tinggi maka hal tersebut akan berbanding linier dengan hasil belajar siswa yang meningkat, (Scraw \& Dennison 1994).

Berdasarkan tabel distribusi kategori kesadaran metakognitif siswa juga menunjukan kecenderungan variabel kesadaran metakognitif siswa berada pada kategori sedang yaitu sebanyak 135 siswa $(53,7 \%)$. Siswa yang memiliki kategori Tinggi sebanyak $(42,4 \%)$, sedangkan kesadaran metakogntif siswa yang berada pada kategori Rendah hanya $(4,4 \%)$. Presentasi hasil kesadaran metakognitif berdasarkan indikator kesadaran metakognitif. Ketercapaian keseluruhan indicator kesadaran metakognitif rata-rata adalah $73,12 \%$ dengan kriteria Baik.

Siregar (2014) menjelaskan pada dimensi pengetahuan salah satu kategori yang berpengaruh pada hasil belajar kognitif salah satunya adalah kategori Prosedur (prosedural knowladge). Prosedural knowladge menurutnya merupakan pengetahuan tentang bagaimana melakukan sesuatu, biasanya berupa seperangkat urutan atau langkah-langkah yang harus diikuti. Dalam penelitian ini Prosedural knowladge merupakan salah satu indikator kesadaran metakognitif yang termasuk dalam pengetahuan metakognitif (knowledge metacognitive). Indikator Prosedural knowladge yang dicapai siswa dalam penelitian ini adalah $77,8 \%$ dengan kriteria baik. Artinya berdasarkan hasil penelitian Indikator Prosedural knowladge mempunyai pengaruh terhadap hasil belajar kognitif. Hal tersebut selaras dengan teori yang menyatakan bahwa Indikator Prosedural knowladge merupakan salah satu faktor intern yang berpengaruh terhap hasil belajar kognitif.

Siregar (2014) menjelaskan kembali bahwa kemampuan intelektual, dan kemampuan mengingat merupakan salah satu faktor intern yang berpengaruh terhadap hasil belajar kognitif. Selain itu menurut Ula (2013) faktor intern yang mempengaruhi hasil belajar kognitif adalah salah satunya intelegensi dan kemampuan kognitif. Menurut Fauziyah dkk (2013), kemampuan intelektual memegang peranan besar terhadap tinggi rendahnya taraf prestasi belajar, khususnya dalam pembelajaran yang menuntut banyak pemikiran misalnya sains.

Karena Menurut Schraw at. all (1994) "Declarative Knowledge is, Knowledge of one's skills, intellectual resources, and abilities as a learner". Pengetahuan deklaratif merupakan Pengetahuan tentang keterampilan seseorang, sumber daya intelektual, dan kemampuan sebagai seorang pelajar. Dari penjelasan tersebut, secara garis besar faktor internal yang berpengeruh terhap hasil belajar salah salah satu nya adalah kemampuan intelektual (intelejensi) dan kemampuan kognitif. Kedua faktor tersebut termasuk kedalam indicator pengetahuan deklaratif (Declarative Knowledge) yang merupakan salah satu indikator kesadaran metakognitif. Artinya 
Quagga: Jurnal Pendidikan dan Biologi

Volume 10, Nomor 2, Juli 2018

kesadaran metakognisi merupakan salah satu faktor yang mempengaruhi hasil belajar.

Selain itu ketercapaian indikator metakognisi siswa lainya adalah pengetahuan kondisional dan perencanaan. yaitu dengan capaian $77,8 \%$ dan $68,2 \%$ dengan kriteria baik. Menurut Nurmalasari (2012) Pengetahuan kondisional merupakan kesadaran kondisi situasi belajar dan mengetahui alasan mengapa menggunakan atau memilih suatu strategi tertentu. Sedangkan keterampilan perencanaan merupakan keterampilan merancang sesuatu yang akan dilakukan. Keterampilan perencanaan meliputi merencanakan dan menetapkan tujuan sebelum belajar, dalam hal ini siswa mengidentifikasi dan mengaktifkan kemampuan, taktik, dan prosesproses tertentu yang akan digunakan untuk mencapai tujuan belajarnya. Nuryana dan Sugiarto (2012), menyatakan bahwa hubungan antara planning skill dan hasil belajar siswa diperoleh nilai $r$ sebesar 0,701 dengan interpretasi hubungan cukup.

Berdasarkan penjelasan di atas, keduanya berkaitan dengan kebiasaan belajar, tentang bagaimana siswa menyesuaikan strategi belajar dalam kondisi apapun dan membuat target atau capaian dalam belajar. Menurut Siregar (2014) kebiasaan belajar merupakan salah satu faktor yang dapat berpengaruh terhadap hasil belajar kognitif.

Indikator kesadaran metakognitif lainya yang dijadikan penelitian, yaitu comprehension monitoring dan Evaluation. Berdasarkan hasil penelitian keduanya mencapai nilai $77,7 \%$ dan 75,6\% dengan kriteria baik. Capaian itu selaras dengan hasil kajian Nuryana dan Sugiarto (2012) yang menemukan bahwa hubungan antara keterampilan monitoring dan hasil belajar siswa diperoleh nilai $\mathrm{r}$ sebesar 0,866 dengan interpretasi hubungan tinggi, dan hubungan antara keterampilan mengevaluasi dan hasil belajar siswa diperoleh nilai $r$ sebesar 0,844 dengan interpretasi hubungan tinggi.

\section{Pengaruh Gender dan Kesadaran Metakognitif Secara Bersama-sama terhadap Hasil Belajar Biologi Siswa}

Hasil kajian menunjukkan bahwa gender dan kesadaran metakognitif secara bersama-sama dinyatakan berpengaruh terhadap hasil belajar biologi. Sedangkan untuk mengetahui presentase pengaruh gender dan kesadaran metakognitif secara bersama-sama terhadap hasil belajar dapat dilihat dari nilai R2 (adjusted $R$ square)
p-ISSN 1907-3089, e-ISSN2651-5869

https://journal.uniku.ac.id/index.php/quagga

adalah 0,597. Jadi sumbangan pengaruh dari variabel independen secara bersama-sama yaitu $59,7 \%$. Adapun sisanya 40,3\% dipengaruhi oleh faktor lain yang tidak diteliti.

Bentuk pengaruh antara gender dan kesadaran metakognitif secara bersama-sama terhadap hasil belajar biologi adalah pengaruh positif yang ditunjukkan dari harga koefisien regresi yang bertanda positif. Dengan demikian dapat dijelaskan bahwa jika variabel gender dan kesadaran metakognitif lebih diperbaiki, maka akan diikuti dengan meningkatnya hasil belajar biologi dan sebaliknya jika variabel gender dan kesadaran metakognitif menurun, maka akan diikuti dengan menurunnya hasil belajar biologi yang dicapai.

\section{SIMPULAN}

Hasil belajar biologi di SMA ternyata tidak dipengaruhi oleh gender.

Akan tetapi gender dan kesadaran metakognitif secara bersama-sama mempengaruhi hasil belajar biologi. Adapun kesadaran metakognitif yang dimiliki siswa berpengaruh terhadap hasil belajar biologi. Besarnya pengaruh kesadaran metakognitif terhadap hasil belajar biologi siswa berada pada taraf sangat signifikan. Jika variabel gender dan kesadaran metakognitif lebih diperbaiki, akan diikuti dengan meningkatnya hasil belajar biologi. Sebaliknya jika variabel gender dan kesadaran metakognitif menurun, maka akan diikuti dengan menurunnya hasil belajar biologi.

\section{REFERENSI}

Arikunto, S. 2012. Prosedur Penelitian: Suatu Pendekatan Praktik. Jakarta: Rineka Cipta.

Badan Koordinasi Keluarga Berencana Nasional (BKKBN). 2009. Konsep dan Teori Gender (Cetakan ke 2). Badan Koordinasi Keluarga Berencana Nasional. Jakarta.

Coutinho, S. A. 2007. The Relationship Between Goals, Metacognition, and Academic Success. Educate. 7 (1):hal 39-40.

Dryden, G-, \& Vos, J. 2001. The Learning Revolution. Diterjemaahkan oleh: Baiquni, Ahmad. Bandung: Penerbit Kaifa

Fauziyah, D. R, Corebima, A. D, \&Zubaidah, S. 2013. Hubungan Keterampilan 
Quagga: Jurnal Pendidikan dan Biologi

Volume 10, Nomor 2, Juli 2018

Metakognitif terhadap Hasil Belajar Biologi dan Retensi Siswa Kelas X dengan Penerapan Strategi Pembelajaran Think Pair Share di SMA Negeri 6 Malang. Thesis Universitas Negeri Malang

Huda, M. 2014. Model-model pengajaran dan pembelajaran (edisi ke 5). Yogyakarta : Pustaka Belajar.

Kristiani, N. 2013. Hubungan Keterampilan Metakognitif dan Hasil Belajar Kognitif Siswa pada Pembelajaran Saintifik dalam Mata Pelajaran Biologi SMA Kurikulum 2013. Makalah disampaikan dalam Prosiding Seminar Nasional X Pendidikan Biologi FKIP UNS. Surakarta: di laksanakan tanggal 06 Juli 2013.

Pusat Data dan Statistik Pendidikan dan Kebudayaan. 2016. Statistik Sekolah Menengah Atas (SMA) 2015/2016. Kemdikbud, Jakarta.

Kusumaningtias, A. Zubaidah, S. \& Indriwati, S, E. 2013. Pengaruh Problem Based Learning Dipadu Strategi Numbered Heads Together Terhadap Kemampuan Metakognitif, Berpikir Kritis, dan Kognitif Biologi. Jurnal Penelitian Pendidkan. Vol 23 (1) : hal. 23

Nugrahaningsih, T. K. 2012. Metakognisi Siswa SMA Kelas Akselerasi Dalam Memecahkan Soal Matematika. Magistra. No. 82 Th. XXIV Desember 2012. ISSN 0215-9511

Nurmalasari, L. R ., Winarso, W., \& Nurhayati, E. 2015. Pengaruh Kemampuan Metakognisi terhadap Hasil Belajar Matematika di SMP Negeri 2 Leuwimunding Kabupaten Majalengka. Nusantara Of Research. Vol- 02 (02) : Hal. 133-147.

Nuryana, E. \& Sugiarto, B. 2012. Hubungan Keterampilan Metakognisi Dengan Hasil Belajar Siswa Pada Materi Reaksi Reduksi Oksidasi (Redoks) Kelas X-1 SMANegeri 3 Sidoarjo. Unesa Journal of Chemical Education. Vol. 1 (1); hal. 83-75.
p-ISSN 1907-3089, e-ISSN2651-5869

https://journal.uniku.ac.id/index.php/quagga

Ormrod, E. J. 2009. Psikologi Pendidikan (edisi ke 6). Jakarta: Erlangga.

Organisation for Economic Co- operation and Development (OECD). 2016. PISA: Results In Focus. OECD: Paris France

Pambudiono, A. Zubaidah, S. \& Mahanal, S. 2013. Perbedaan Kemampuan Berpikir dan Hasil Belajar Biologi Siswa Kelas X SMA Negeri 7 Malang Berdasarkan Jender dengan Penerapan Strategi Jigsaw. Laporan Penelitian. Universitas Malang (e-journal. um. ac. id).

Rahman, S. \& Philips, J. A. 2006. Hubungan antara Kesedaran Metakognisi, Motivasi dan Pencapaian Akademik Pelajar Universiti. Jurnal Pendidikan, 31; hal. 2139.

Ramdiah, S. 2013. Pengaruh Strategi Pembelajaran PQ4R Terhadap Keterampilan Metakognitif dan Hasil Belajar Biologi Siswa Putra dan Putri Kelas XI Sma di Kota Banjarmasin. Makalah disampaikan dalam Prosiding Seminar Nasional X Pendidikan Biologi FKIP UNS. Surakarta : di laksanakan tanggal 06 Juli 2013.

Santrock, J. W. 2009. Psikologi Pendidiakan Educational Psiokologi (Edisi ke 3). Jakarta : Salemba Humanika.

Sumampouw, M. H. 2011. Ketrampilan Metakognitif dan Berfikir Tingkat Tinggi dalam Pembelajarn Genetika. Bioedukasi. Vol 4 (2) : hal. 23-39.

Saenab, S. dan Arifin, N. A. 2014. Perbandingan Kesadaran Metakognitif Siswa yang Diajar Menggunakan Model Problem-Based Instruction (PBI) dengan Kooperatif Tipe Think Pair Share (TPS). Jurnal Bionature. Vol.15 (2): hal. 81-89.

Sasser, L. 2010. Brain Differences between Genders. Gender Differences in Learning, Genesis 5:1-2, (Online), (http://www.faccs.org/assets/Conventions/ Convention-10/Workshops/Sasser-GenderDifferences-in-Learning.pdf), diakses tanggal 13 Juli 2017. 
Quagga: Jurnal Pendidikan dan Biologi

Volume 10, Nomor 2, Juli 2018
p-ISSN 1907-3089, e-ISSN2651-5869

https://journal.uniku.ac.id/index.php/quagga

Schraw, G. \& Moshman, D. 1995. Metacognitive theories. Educational Psychology Review.Vol 7(4) : hal. 351-371.

Schraw, G. \& Dennison, R. S. 1994. Assessing metacognitive Awareness. Contemporary Educational Psychology. P.19. hal. 460475 .

Siregar, E. \& Nara, H. 2014. Teori Belajar dan Pembelajaran. Bogor: Ghalia Indonesia

Siregar, S. 2015. Metode Penelitian Kuantitatif dilengkapi dengan perhitungan Manual \& SPSS (Cetakan ke 3). Jakarta : Pranadamedia Group.

Sudia M. 2015. Profil Metakognisi Siswa Smp Dalam Memecahkan Masalah Openended Ditinjau Dari Tingkat Kemampuan Siswa. Jurnal Math Educator Nusantara. Vol. 1 (01) : Hal. 05-25

Suendi, D. A. P. 2016. Pengaruh Strategi Pembelajaran Learning Start With A Question (LSQ) Melalui Lesson Study Terhadap Metakognisi Dan Hasil Belajar Biologi Siswa (Kelas XI IPA MAN 2 Jember Tahun Pelajaran 2015/2016). Skripsi. Fakultas Keguruan dan Ilmu Pendidikan Universitas Jember.

Sugihartono. Nur Fathiyah, K. Harahap, F. 2007. Psikologi Pendidikan. Yogyakarta : UNY Press.

Suyono \& Haryanto. 2014. Belajar dan Pembelajaran (Teori dan Konsep Dasar). Bandung: PT. Remaja Posdakarya.

Ula, S. 2013. Revolusi Belajar (Cetakan ke 1). Yogyakarta : Ar-Ruzz Media.

Yuniarti, R. D. 2014. Pengaruh Sikap dan Gender Terhadap Prestasi Belajar Bahasa Indonesia Pada Siswa SMP Negeri Kelas VII di Kecamatan Sleman Yogyakarta 2013/2014. Skripsi. Fakultas Bahasa dan Seni, Universitas Negeri Yogyakarta, Yogyakarta. 